УДК 349.41: 346.93

I. В. Маслій

суддя господарського суду Вінницької області, дочент кафедри господарського права

Донецького національного університету імені Василя Стуса, канд. юрид. наук

\title{
ОСОБЛИВОСТІ ЗАСТОСУВАННЯ СТАТТІ ЗЗ ЗАКОНУ УКРАЇНИ «ПРО ОРЕНДУ ЗЕМЛІ» У ГОСПОДАРСЬКОМУ ПРОЦЕСІ: ОГЛЯД СУДОВОЇ ПРАКТИКИ
}

Ключові слова: орендар, орендодавеиь, договір оренди, поновлення договору, державна реєстрачія договору, додаткова угода, земельні спори.

Статтею 14 Конституції України визначено, що земля $є$ основним національним багатством, що перебуває під особливою охороною держави. Право власності на землю гарантується. Це право набувається і реалізується громадянами, юридичними особами та державою виключно відповідно до закону [1]. Аналогічний зміст носить стаття 1 Земельного кодексу України [2].

При розгляді господарськими судами земельних спорів досить часто виникають колізії у застосуванні норм законодавства, що регулюють земельні відносини. Зокрема, існує проблема щодо застосування статті 33 Закону України «Про оренду землі» під час розгляду спорів, пов'язаних 3 продовженням/ пролонгацією укладених договорів оренди земельних ділянок державної та комунальної форми власності.

Статтями 1, 3, 6, 17 Закону України «Про оренду землі» (далі - Закон) зокрема визначено, що оренда землі - це засноване на договорі строкове платне володіння і користування земельною ділянкою, необхідною орендареві для проведення підприємницької та інших видів діяльності. Об'єктами оренди є земельні ділянки, що перебувають у власності громадян, юридичних осіб, комунальній або державній власності. Орендодавцями земельних ділянок, що перебувають у комунальній власності, є сільські, селищні, міські ради в межах повноважень, визначених законом. Право оренди земельної ділянки підлягає державній реєстрації відповідно до закону. Об'єкт за договором оренди землі вважається переданим орендодавцем орендареві з моменту державної реєстрації права оренди, якщо інше не встановлено законом [3].

Статтею 33 Закону встановлено порядок продовження договору оренди землі державної та комунальної форми власності з особою, яка належним чином виконувала умови договору на новий строк. Відповідно до цього порядку по закінченню строку, на який було укладено договір оренди землі, орендар, який належно виконував обов'язки за умовами договору, має переважне право перед іншими особами на укладення договору оренди землі на новий строк (поновлення договору оренди землі). 
Орендар, який має намір скористатися переважним правом на укладення договору оренди землі на новий строк, зобов'язаний повідомити про це орендодавця до спливу строку договору оренди землі у термін, що встановлений цим договором, але не пізніше ніж за місяць до спливу строку договору. До листа-повідомлення про поновлення договору оренди землі орендар додає проект додаткової угоди.

Орендодавець у місячний термін розглядає надісланий орендарем листповідомлення $з$ проектом додаткової угоди, перевіряє його на відповідність вимогам закону, узгоджує з орендарем (за необхідності) істотні умови договору $\mathrm{i}$, за відсутності заперечень, приймає рішення про поновлення договору оренди землі (щодо земель державної та комунальної власності), укладає з орендарем додаткову угоду про поновлення договору оренди землі. За наявності заперечень орендодавця щодо поновлення договору оренди землі орендарю направляється лист-повідомлення про прийняте орендодавцем рішення.

У разі якщо орендар продовжує користуватися земельною ділянкою після закінчення строку договору оренди і за відсутності протягом одного місяця після закінчення строку договору листа-повідомлення орендодавця про заперечення у поновленні договору оренди землі, такий договір вважається поновленим на той самий строк і на тих самих умовах, які були передбачені договором. У цьому випадку укладання додаткової угоди про поновлення договору оренди землі здійснюється із:

власником земельної ділянки (щодо земель приватної власності);

уповноваженим керівником органу виконавчої влади або органу місцевого самоврядування без прийняття рішення органом виконавчої влади або органом місцевого самоврядування про поновлення договору оренди землі (щодо земель державної або комунальної власності).

Додаткова угода до договору оренди землі про його поновлення має бути укладена сторонами у місячний строк в обов'язковому порядку [3].

25 лютого 2015 року Верховний Суд України ухвалив постанову у справі № 6-219цс14, у якій дійшов висновку, що стаття 33 Закону об’єднує два різних випадки пролонгації договору оренди землі.

У першому випадку, для застосування частини першої статті 33 Закону та визнання за орендарем переважного права на поновлення договору оренди необхідно встановити такі юридичні факти:

орендар належно виконує свої обов'язки за договором;

орендар до спливу строку договору повідомив орендодавця у встановлені строки про свій намір скористатися переважним правом укладення договору на новий строк;

до листа-повідомлення орендар додав проект додаткової угоди;

орендодавець протягом місяця не повідомив орендаря про наявність заперечень та про своє рішення.

У другому випадку, частиною шостою статті 33 Закону передбачена інша підстава поновлення договору оренди, а саме: у тому разі, якщо орендар продовжує користуватися земельною ділянкою після закінчення строку 
договору оренди і за відсутності протягом одного місяця після закінчення строку договору листа-повідомлення орендодавця про заперечення у поновленні договору оренди землі, такий договір вважається поновленим на той самий строк і на тих самих умовах, які були передбачені договором.

Таким чином, для поновлення договору оренди землі з підстав, передбачених частиною шостою статті 33 Закону, необхідна наявність таких юридичних фактів:

орендар продовжує користування виділеною земельною ділянкою;

орендар належно виконує свої обов'язки за договором;

відсутнє письмове повідомлення орендодавця про відмову у поновленні договору оренди;

сторони укладають додаткову угоду про поновлення договорів оренди.

У цій постанові Верховний Суд України дійшов висновку про те, що порушення переважного права орендаря, яке підлягає захисту відповідно до статті 3 Цивільного кодексу України, матиме місце:

при укладенні договору оренди із новим орендарем при отриманні письмового повідомлення попереднього орендаря про намір реалізувати переважне право;

у випадку недосягнення згоди щодо плати за новим договором та інших умов договору $з$ іншим наймачем на більш сприятливих умовах та укладення 3 ним договору на тих самих умовах, які запропоновані попереднім наймачем при реалізації переважного права;

у разі укладення договору з новим орендарем за умови, що підставою відмови попередньому орендарю у поновленні договору оренди було повідомлення орендодавця про необхідність використовувати об'єкт оренди для власних потреб [4].

За результатами розгляду вищевказаної справи Верховний Суд України розробив правовий висновок для судів усіх інстанцій та осіб, що є суб'єктами земельних відносин, яким декларує те, що встановивши факт належного виконання орендарем умов договору оренди; дотримання ним строків та процедури повідомлення про намір реалізувати своє переважне право на поновлення договору оренди на новий строк; ненадіслання орендодавцем у встановлений законом строк відмови у поновленні договору на новий строк; укладення орендодавцем договору оренди 3 іншим орендодавцем на таких самих умовах, які запропоновані попереднім орендарем; продовження використання ним земельної ділянки після закінчення строку дії договору - суд не має підстав відмовляти позивачу у задоволенні позову про поновлення договору оренди землі на новий строк.

Цією постановою Верховний Суд України врегулював протиріччя, які існували у судах під час розгляду такої категорії спорів.

Однак, залишилося відкритим питання стосовно того, коли саме настає строк, у межах якого орендар повинен повідомити орендодавця про бажання продовжити дію договору. 
Як зазначалося вище, право оренди земельної ділянки підлягає державній реєстрації відповідно до закону.

Статтею 210 Цивільного кодексу України визначено, що правочин підлягає державній реєстрації лише у випадках, встановлених законом. Такий правочин $є$ вчиненим з моменту його державної реєстрації [6].

Стаття 17 Закону вказує на те, що об'єкт за договором оренди землі вважається переданим орендодавцем орендареві з моменту державної реєстрації права оренди, якщо інше не встановлено законом [3].

19 лютого 2014 року Верховний Суд України ухвалив постанову у справі № 6-162цс13, у якій дійшов висновку, що договір є укладеним, якщо сторони в належній формі досягли згоди 3 усіх істотних умов договору. Істотними умовами договору є умови про предмет договору, умови, що визначені законом як істотні або є необхідними для договорів даного виду, а також усі ті умови, щодо яких за заявою хоча б однієї із сторін має бути досягнуто згоди.

Тобто, сторони договору, дійшовши згоди щодо всіх істотних умов договору оренди землі, складають і підписують договір, надаючи згоді встановленої форми.

Разом із тим цивільні права та обов'язки, на досягнення яких було спрямоване волевиявлення сторін при укладенні спірних договорів, набуваються після відповідної державної реєстрації [5].

Таким чином, Верховний Суд України у вказаній постанові визначив, що моментом укладення договору є досягнення сторонами згоди щодо усіх істотних умов договору оренди землі, скріпивши дану згоду своїми підписами. Разом із тим цивільні права та обов'язки, на досягнення яких спрямоване волевиявлення сторін договору оренди, набуваються після відповідної державної реєстрації. В момент державної реєстрації набирає чинності (набуває юридичної сили) договір, укладення якого вже відбулося, і така реєстрація не може змінювати моменту укладання договору.

Вказаний правовий висновок було зроблено у зв'язку з тим, що статтею 17 Закону України «Про оренду землі» (в редакції, що діяла до 12.02 .2015 року) передбачалося, що передача об'єкта оренди орендарю здійснюється орендодавцем у строки та на умовах, що визначені у договорі оренди землі, за актом приймання-передачі, тобто законом було чітко визначено момент передачі земельної ділянки від орендодавця до орендаря.

Однак Законом України від 12.02.2015 р. № 191-VIII «Про внесення змін до деяких законодавчих актів України щодо спрощення умов ведення бізнесу (дерегуляція)» до статті 17 Закону «Про оренду землі» внесено зміни та визначено, що об'єкт за договором оренди землі вважається переданим орендодавцем орендареві 3 моменту державної реєстрації права оренди, якщо інше не встановлено законом.

У свою чергу будь-яким іншим нормативно-правовим актом не встановлено моменту переходу земельної ділянки від орендодавця до орендаря. 
У зв'язку зі змінами, що відбулися в законодавстві, а саме у статті 17 Закону «Про оренду землі» Верховним Судом України прийнято низку постанов 3 іншим правовим висновком щодо моменту укладення договору оренди землі:

постанова Верховного Суду України від 18.01.2017 у справі № 6-2777цс16; постанова Верховного Суду України від 27.04.2017 у справі № 6-422цс17; постанова Верховного Суду України від 07.06.2017 у справі № 6-872цс17.

У вказаних вище судових актах визначено, що згідно із частиною першою статті 638 Цивільного кодексу України договір є укладеним, якщо сторони в належній формі досягли згоди 3 усіх істотних умов договору. Істотними умовами договору є умови про предмет договору, умови, що визначені законом як істотні або є необхідними для договорів даного виду, а також усі ті умови, щодо яких за заявою хоча б однієї із сторін має бути досягнуто згоди.

Правочин підлягає державній реєстрації лише у випадках, встановлених законом. Такий правочин $\epsilon$ вчиненим 3 моменту його державної реєстрації (частина перша статті 210 ЦК України).

Відповідно до частини другої статті 792 ЦК України відносини щодо найму (оренди) земельної ділянки регулюються законом.

Спеціальним законом, яким регулюються відносини, пов'язані з орендою землі, є Закон України «Про оренду землі». За змістом статей 18, 20 цього Закону (у редакції, яка була чинною на момент виникнення спірних правовідносин) договір оренди землі набирає чинності після його державної реєстрації. Укладений договір оренди землі підлягає державній реєстрації. Державна реєстрація договорів оренди землі проводиться у порядку, встановленому законом.

Отже, строк дії договору оренди землі, умовами якого передбачено, що відлік строку оренди настає з моменту державної реєстрації цього договору, починається після набрання ним чинності, а не з моменту його укладення.

Набрання договором чинності є моментом у часі, коли починають діяти права та обов'язки за договором, тобто коли договір (як підстава виникнення правовідносин та письмова форма, в якій зафіксовані умови договору) породжує правовідносини, на виникнення яких було спрямоване волевиявлення сторін [7, 8, 9].

Таким чином, Верховний Суд України у вказаних постановах змінив практику у встановленні моменту укладення правочину та визначив, що моментом укладення договору $є$ саме його державна реєстрація, а не його підписання, відповідно відлік терміну дії договору починається з дати державної реєстрації.

Стаття 111-28 Господарського процесуального кодексу України в редакції від 06.11.1991 року визначала, що висновок Верховного Суду України щодо застосування норми права, викладений у його постанові, прийнятій за результатами розгляду справи з підстав, передбачених пунктами 1 і 2 частини першої статті 111-16 цього Кодексу, є обов'язковим для всіх суб'єктів владних повноважень, які застосовують у своїй діяльності нормативно-правовий акт, що містить відповідну норму права. Висновок щодо застосування норм права, 
викладений у постанові Верховного Суду України, має враховуватися іншими судами загальної юрисдикції при застосуванні таких норм права. Суд має право відступити від правової позиції, викладеної у висновках Верховного Суду України, з одночасним наведенням відповідних мотивів. Невиконання судових рішень Верховного Суду України тягне за собою відповідальність, установлену законом. Постанови Верховного Суду України, прийняті за результатами розгляду заяв про перегляд судового рішення, підлягають опублікуванню на офіційному веб-сайті Верховного Суду України не пізніше як через п’ятнадцять днів $з$ дня їх прийняття [10].

Тобто Господарський процесуальний кодекс України у попередній редакції не лише зобов'язував суди нижчих інстанцій та суб'єкти владних повноважень, які застосовують у своїй діяльності нормативно-правовий акт, що містить відповідну норму права, враховувати висновки щодо застосування норм права, викладені у постановах Верховного Суду України, а й передбачав відповідальність за їх невиконання.

У свою чергу змінами, що відбулися у господарському процесі на підставі Закону України від 03.10.2017 № 2147-VIII «Про внесення змін до Господарського процесуального кодексу України, Цивільного процесуального кодексу України, Кодексу адміністративного судочинства України та інших законодавчих актів» що вступив у дію з 15.12.2017 року, виключено таке положення, як обов'язковість врахування висновків Верховного Суду України, однак частиною 4 статті 236 Господарського процесуального кодексу України у новій редакції, із заголовком «Законність і обгрунтованість судового рішення» визначено, що при виборі і застосуванні норми права до спірних правовідносин суд враховує висновки щодо застосування норм права, викладені у постановах Верховного Суду України [11].

Таким чином, є підстави вважати, що висновки, викладені у постановах Верховного Суду України, повинні враховуватися судами при застосуванні норми права до спірних правовідносин, хоч такого обов'язку і не передбачається.

Отже, господарські суди при розгляді справ про поновлення договорів оренди землі зобов'язані враховувати висновки Верховного Суду України про те, що відлік строку оренди настає 3 моменту державної реєстрації цього договору, а не з моменту його укладення.

Однак, поряд 3 відповідними правовими висновками касаційного суду виникають інші питання, 3 якими стикаються суди під час розгляду спорів відповідної категорії.

Як зазначалося вище, за договором оренди землі комунальної власності орендодавцями земельних ділянок є сільські, селищні, міські ради в межах повноважень, визначених законом [3].

Право оренди земельної ділянки підлягає державній реєстрації відповідно до закону. Об'єкт за договором оренди землі вважається переданим орендодавцем орендареві з моменту державної реєстрації права оренди, якщо інше не встановлено законом [3]. 
Законом чітко не визначено суб'єкта, на якого б покладався обов'язок подавати договір на реєстрацію, а за загальним правилом такою особою $є$ орендар.

Також Законом не визначено і строку, протягом якого орендар або будьяка інша уповноважена особа зобов'язані подати договір на реєстрацію.

Отже, виникає питання, якщо, наприклад, договір оренди укладено на 10 років, а його державна реєстрація здійснюється через 5-7 років після його підписання, то 3 якого часу повинен обраховуватися строк дії договору: 3 дня його підписання чи з дня державної реєстрації?

Відповідно до статті 206 Земельного кодексу України використання землі в Україні є платним. Об'єктом плати за землю є земельна ділянка. Плата за землю справляється відповідно до закону [2].

За предметом відповідного Типового договору оренди землі, затвердженого постановою Кабінету Міністрів України від 03.03.2004 року № 220, орендодавець (у випадку, що розглядається, це орган місцевого самоврядування) надає, а орендар приймає у строкове платне користування земельну ділянку [12].

Тобто, земельну ділянку передає у користування саме власник землі в особі органу місцевого самоврядування, а державну реєстрацію договору може здійснювати інша особа, визначена статтею 6 Закону України «Про державну реєстрацію речових прав на нерухоме майно та їх обтяжень» [13].

Відсутність у законі чіткого визначення моменту укладення договору може призвести до зловживань з боку орендаря, а саме: штучного продовження терміну дії договору шляхом його більш пізньої реєстрації, а також ухилення від сплати за оренду землі та відповідних податків, адже плата за договором здійснюється після його укладання, а як зазначалося вище - договір вважається укладеним $з$ дня його державної реєстрації.

Для врегулювання спірних питань, щзо можуть виникати під час реалізації права оренди землі, визначеного статтею 33 Закону Украӥни «Про оренду землі», статтю 17 изього Закону пропонується викласти у такій редакиій: «Об'єкт за договором оренди землі вважається переданим орендодавием орендареві з моменту державної реєстраиії права оренди та після підписання акту приймання-передачі, якщзо інше не встановлено законом».

1. Конституція України: Прийнята на п'ятій сесії Верховної Ради України 28 червня 1996 р. № 254к/96-ВР. Відомості Верховної Ради України. 1996. № 30. Ст. 141. (Із змінами).

2. Земельний кодекс України: Закон України від 25 жовтня 2001 p. № 2768-III. Відомості Верховної Ради Украӥни. 2002. № 3-4. Ст. 27. (Із змінами).

3. Про оренду землі: Закон України від 6 жовтня 1998 р. № 161-XIV. Відомості Верховної Ради України. 1998. № 46-47. Ст. 280. (Із змінами).

4. Постанова Верховного Суду України від 25 лютого 2015 р. у справі № 6-219цс14. URL: http://www.scourt.gov.ua/clients/vsu/vsu.nsf/(documents)/898BF55749E90EC3C2257DF900 3ED0E4. 
5. Постанова Верховного Суду України від 19 лютого 2014 р. у справі № 6-162цс13. URL: http://www.scourt.gov.ua/clients/vsu/vsu.nsf/(documents)/CF2A5FA58DAC2679C2257C920 03A7024.

6. Цивільний кодекс України: Закон України від 16 січня 2003 р. № 435-IV. Офіційний вісник Украӥни. 2003. № 11. Ст. 461. (Із змінами).

7. Постанова Верховного Суду України від 27 квітня 2017 р. у справі № 6-422цс17. URL: http://www.scourt.gov.ua/clients/vsu/vsu.nsf/(documents)/C9EEFE46693C1735C2258122002 AE7D8.

8. Постанова Верховного Суду України від 18 січня 2017 р. у справі № 6-2777цс16. URL: http://www.scourt.gov.ua/clients/vsu/vsu.nsf/(documents)/D141A36494BF6E3FC22580B300 2964D4.

9. Постанова Верховного Суду України від 7 червня 2017 р. у справі № 6-872цс17. URL: http://www.scourt.gov.ua/clients/vsu/vsu.nsf/(documents)/8E715790F097866CC2258146005 A7C84

10. Господарський процесуальний кодекс України в редакції від 6 листопада 1991 р. Відомості Верховної Ради України. 1992. № 6. Ст. 56.

11. Про внесення змін до Господарського процесуального кодексу України, Цивільного процесуального кодексу України, Кодексу адміністративного судочинства України та інших законодавчих актів: Закон України від 3 жовтня 2017 р. № 2147-VIII. Відомості Верховної Ради України. 2017. № 48. Ст. 436.

12. Про затвердження Типового договору оренди землі: Постанова Кабінету Міністрів України від 3 березня 2004 р. № 220. Офіиійний вісник Украӥни. 2004. № 9. Ст. 527. (Із змінами).

13. Про державну реєстрацію речових прав на нерухоме майно та їх обтяжень: Закон України від 1 липня 2004 р. № 1952-IV. Відомості Верховної Ради України. 2004. № 51. Ст. 553. (Із змінами).

УдК 346.6:35.073.53(477)

Д. В. Корчевець

здобувач, провідний юрисконсульт

Донецького національного

університету імені Василя Стуса

\section{ОГЛЯД ПРАКТИКИ ДОПОРОГОВИХ ЗАКУПІВЕЛЬ З ВИКОРИСТАННЯМ СИСТЕМИ РROZORRO}

Ключові слова: публічні закупівлі, допорогові закупівлі, електронна система закупівель, система PROZORRO, етапи закупівель.

Сфера державних закупівель завжди вважалась однією з найбільш проблемних та сприятливих для корупційних правопорушень. Кардинальна реформа державних закупівель відбулася в Україні після прийняття нового Закону України «Про публічні закупівлі» (далі - Закон) від 25 грудня 2015 року [1].

Можна стверджувати, що прийняття цього Закону уособило перехід до нового розуміння закупівель: вони перестали бути «державними» на користь «публічних» 3 акцентом, що такі закупівлі проводяться за гроші громадян та їх 